\title{
My Mother's Secret
}

\author{
by J.L. Witterick
}

Published by the Penguin Group, 2013, 195 pages

\section{Reviewed by}

Carlos A. Santana (carlos.santana@trident.edu), Academic Advising Manager, Trident University International

J. L. Witterick shares her gift of writing through a wonderful novel inspired by historical events that will captivate its readers from beginning to end. Because it is a short read, readers may be captivated by the story and characters enough to read it in one sitting. There is much depth found in the content that describes an era in our history succinctly and vividly, without gory or graphic details. However, readers will obtain a very genuine understanding of what it was like to live during the Holocaust from different points of view. The variation in storytelling from the point of view of several characters makes this a stunning piece of literary artwork. Inspiration is derived from the compassion, intellect, and bravery displayed by Franciszka and Helena. In addition, a sense of hope in humanity during inhumane times further demonstrates the power of making a difference against all odds.

The events of the Holocaust have tainted a piece of recent human history. However, Holocaust survival stories illuminate the darkest corners of humanity and stimulate hope, courage, and certainty during tumultuous times. There are many lessons to be learned from our history that serve as reminders for the direction of our future. My Mother's Secret continues the tradition of sharing wisdom through a fictional portrayal of the lives of Franciszka Halamajowa and her daughter, Helena, which is inspired by a true Holocaust story. Franciszka and Helena believe that when people "choose to do the right thing, it's a conscious decision at first. Then it becomes second nature. You don't have to think about what is right because doing the right thing becomes who you are, like a reflex. Your actions with time become your character" (p. 11).

With their convictions intact, Franciska and Helena help those in need by providing shelter, food, and medicine after Nazi Germany invades Poland in 1939. Their heroism is admirable, particularly after they manage to make their home the center of four different perspectives under the same roof. A rich Jewish family hides under the kitchen floor boards, a poor Jewish family hides in the loft above the pig sty, and a defecting German soldier hides in the attic. Because each is being sheltered in different living quarters, they are unaware of the others. Franciska and Helena provide for them all in their small two-bedroom home located in Sokal, Poland. It is important to consider that, in this time period, those that helped the 
Jewish community did not do what is right for the glory, but because their defined character compelled them into immediate action. Dire consequences, including death, awaited individuals caught helping members of the Jewish community during this time period.

J.L. Witterick shares Franciszka's story through the eyes of Helena, her daughter; Bronek, a cattle farm manager that provided wagon rides to Franciszka; Mikolaj, the son of rich Jewish doctor; and Vilheim, a German soldier defecting from the war. Helena dreams of being able to provide for her family so that her brother is not carrying the entire burden for his family. When she receives her first job as the general manager's assistant, Helena falls in love with Casmir, the general manager of the factory. This love becomes one source of hope and security, enabling Helena and her mother to help others. As the war nears, Casmir and Helena must temporarily separate to deal with the struggles of their own families, while finding ways to stay connected. Bronek seeks Franciszka out haphazardly after running out of options and escaping from a Jewish ghetto raided by the Germans. Bronek and his brother kindly provides rides to the market as Franciska carried her eggs to sell. Mikolaj is the son of a rich Jewish doctor and knew Fraciszka because she sold fresh eggs to his family. Lastly, Vilheim met Franciska at a dinner party she hosts for the German commander as a means to network socially and survive. By being hospitable to the Germans and bringing them into her home, she reduces any suspicions of sheltering others. Franciszka is the common link between these four people, yet readers find that their lives intersected prior to being protected in this small living space. Navigating survival when one is providing shelter and aid is not made easy in a time when citizens needed to be careful where they placed their trust, how they spent their time, and how they used resources. Too much utilization of food, water, or medicine could raise suspicions amongst the neighbors, who could turn someone in for the sake of securing their own survival. Members of communities observed common behaviors to deduce suspicious activity.

There are several themes that would make this fascinating book a useful tool for new student programs in higher education. Furthermore, the topic and time period is rich with opportunity for discussion and reflection. Diversity is a rampant theme in this story as characters struggle with respect and trust for those around them. Helena and Franciszka serve as role models, displaying acts of kindness, understanding, and love for their fellow man despite their impoverished and uneducated backgrounds. In total, they sheltered nine people, including two different families in their small home. These individuals were a sampling of different nationalities, social classes, and religions as the Nazi and Russian regimes expanded into Poland. For the sake of survival, it was important that Helena and Franciszka also be hospitable to the commander stationed in the area. They understood that they would not be in a position to help others, or themselves, if they did not negotiate some type of beneficial relationship with the Nazi invaders. New students benefit from lessons in diversity early in their college career. Students will encounter others with different ideas, perspectives, and backgrounds. Being able to accept and understand differences is an important skill 
to develop while in college that will also be beneficial in their future personal and professional lives.

A second theme establishes the importance of family values and support. The idea is not limited to family through a direct relationship, but also includes the family unit people build around themselves that can also be composed of members of their proximal communities. By building trust and love for each other, all characters in this book are motivated to continue their journey, whether living "freely" or in hiding. Everyone, at one point or another, is concerned with their own demise at the hands of the war around them. However, they have to help their respective families to get through this difficult period. When survival instincts are in full gear, the characters reflect on the fact that they have their family to live for and protect. For college students, exploring this theme as they progress through college will be important. Students can begin strategizing the building of an effective student support network by reflecting on their personal needs as they progress through their educational journey.

A third theme, and likely the most obvious and important one, is the ability to maintain hope when challenges seem insurmountable. In fact, rather than displaying constant fear, Franciszka utilized her strengths to ascertain that her household became a safe space in spite of what was happening outside of its walls. Franciszka was also very strategic in building rapport within her local community and would later become a beacon of hope to those she was sheltering. Performing acts of courage on behalf of others yields advocacy efforts that instill a sense of hope within those communities that experience oppression. This can be an educational moment as part of a first-year experience program or service learning program. Students have the ability to make a difference within their respective communities one action item at a time and within much more favorable circumstances today.

My Mother's Secret is highly recommended as a must read for educational programs in higher education. The wisdom encompassed in My Mother's Secret makes for a versatile text that can be used in first-year experience programs, service learning projects, humanities curricula, or to spark conversation within learning communities in the context of student housing. The narrative is very straightforward, and although the stories are simple, there is complexity in the storyline that will engage the reader as connections between the characters and plot are defined. Students will definitely enjoy that this is not a very lengthy reading, yet it is very thought provoking. Topics of discussion can range from diversity and acceptance to hope and motivation for doing the "right" thing. Students can be encouraged to participate in a community service project that will be aligned with themes in the book. Reflection, writing, and discussion in a for-credit course would be a great example of one instructional delivery mechanism that will support student learning. In this context, students would receive both an in-classroom and out-of-classroom experience that connects theoretical frameworks of thought with real-world application strategies. The key in making this a successful learning experience for the students is to provide plenty of opportunity for introspection and dialogue, particularly when diversity conversations can become very emotionally charged. 